\title{
Keharmonisan Keluarga Beda Agama (Studi Fenomena Keharmonisan Keluarga Beda Agama di Kecamatan Sindang Kelingi Kabupaten Rejang Lebong)
}

\author{
Mabrur Syah, Muhammad Arif Mustofa \\ Institut Agama Islam Negeri (IAIN) Curup, Bengkulu \\ aripatmi@gmail.com
}

\begin{abstract}
Expecting to have a family that harmonious and get along well is every family's dream. There are usually individual differences makes it a challenge for the realization of harmony in the family, but not for families in Sindang Kelingi. This study aims to describe the family harmony that occurs in Sindang Kelingi even though with different religions. This study is a descriptive qualitative research in the form of library research, with data collection then analyzed with descriptive data. The data on this Research was obtained through observation, interviews, and documentation. Results of this study are: Religious differences in families that occur in Sindang Kelingi village are formed by the pattern of parents and children. No religious differences were found with married couple andfamily harmony that has diversity in religion can be realized in Sindang Kelingi due to: there are of kinship, the sense of unity, the equality of work / profession of his parents (trans veterans), the advice from the elders to live in harmony, the village regulations for living in harmony and mutual respect the views of moderate religious leaders.
\end{abstract}

Keywords: harmonious, family, different religion

\begin{abstract}
Abstrak
Mengharapkan untuk memiliki keluarga yang harmonis dan rukun adalah dambaan setiap keluarga. Adanya perbedaan indivudu biasanya menjadikan tantangan bagi terwujudnya keharmonisan dalam keluarga, akan tetapi tidak bagi keluarga di Sindang Kelingi. Penelitian ini bertujuan untuk menggambarkan keharmonisan keluarga yang terjadi di kecamatan Sindang Kelingi meskipun berbeda agama. Penelitian ini adalah penelitian kualitatif deskriptif dalam bentuk library research, dengan pengumpulan data kemudian dianalisis dengan data deskriptif. Data penelitian dicari melalui observasi, wawancara, serta dokumentasi. Penelitian ini menghasilkan: bahwa perbedaan agama dalam keluarga yang terjadi di desa Sindang Kelingi terbentuk dengan pola orang tua dan anak. Tidak ditemukan
\end{abstract}


perbedaan agama dengan pasangan suami dan istri dan keharmonisan keluarga yang memiliki keberagaman dalam beragama bisa terwujud di desa Sindang Kelingi dikarenakan: adanya hubungan kekerabatan,perasaan senasib sepenanggungan, kesamaan pekerjaan/profesi orang tuanya (trans veteran), nasihat para sesepuh untuk hidup rukun, peraturan desauntuk hidup harmoni dan saling menghormati serta pandangan tokoh agama yang moderat

Kata Kunci: harmonis, keluarga, beda agama

\section{Pendahuluan}

Keluarga adalah bagian penting dalam sebuah kehidupan. Setiap orang pasti mengharapkan untuk memiliki keluarga yang harmonis dan rukun. Oleh karena itu, menjadi penting bagi setiap orang yang ingin membangun rumah tangga melakukan seleksi dalam menentukan calon pendamping hidupnya baik dari bebet maupun bobotnya. Di samping itu, orang tua juga sangat berperan dalam mewujudkan kerukunan rumah tangga anak-anaknya dengan merestui calon pasangan mereka

Agama sangat konsen dalam memperhatikan urusan keluarga bahkan memberikan gambaran dan cara untuk menentukan pendamping dengan beberapa kriteria mulai dari: nasab, ekonomi, paras, dan agama. Agama inilah yang menjadi hal terpenting di bandingkan dengan yang lainnya.

Selain agama, Negara juga ikut hadir dalam mengatur pernikahan dengan harapan kerukunan dan ketentraman seseorang dalam berkeluarga bisa terwujud. Di antara pasal dalam yang mengartur pernikahan yaitu, bahwa perkawinan dianggap sah jika dilaksanakan dengan prosesi agama tertentu, dengan bunyi pasalnya: "Perkawinan adalah sah, apabila dilakukan menurut hukum masing-masing agamanya dan kepercayaannya itu ${ }^{1}$

Menyatukan dua hal yang berbeda bukan perkara yang mudah, oleh sebab itu dibutuhkan saling pengertian dan tidak memikirkan egonya sendirisendiri.Untuk bisa bersatu dalam membangun keluarga yang rukun dan harmonis setiap pasangan harus bisa menemukan titik kesamaan sehingga perselisihan bisa dikurangi atau bahkan dihindari. Komuniakasi menjadi kunci pokok dalam membangun keluarga, setiap keluarga memiliki cara

${ }^{1}$ Ermi Suhasti, SY, Harmoni Keluarga Beda Agama di Melati, Sleman Yogya.As Syi'ah, 1234 
tersendiri dalam melakukan komunikasi. Pola komunikasi yang digunakan akan sangat berpengaruh terhadap keharmonisan keluarga bahkan yang berbeda keyakinan maupun agama sekalipun. ${ }^{2}$

Adanya fenomena perkawinan antar beda agama pada dasarnya bukan hal yang baru. Meskipun demikian, fenomena ini menjadikan orang tua khawatir terhadap anak-anaknya. Orang tua tentu menginginkan anaknya memiliki keluarga yang seagama sehingga mengurangi konflik dalam keluarga, akan tetapi keinginan orang tua terkadang tidak sejalan dengan keinginan anaknya yang sudah terlanjur merasa cinta dan nyaman dengan pilihannya. Di samping itu, kegelisihan dengan fenomena ini bukan hanya dirasakan oleh orang tua, melainkan juga dirasakan oleh agamawan dan para intelektual. $^{3}$

Adanya perbedaan keyakinan/agama dalam suatu keluarga, tidak jarang menimbulkan ketegangan dan konflik, namun demikian ditemukan beragam fenomena satu keluarga beda agama bisa hidup secara rukun dan harmoni yaitu pada warga masyarakat Desa Sindang Jaya dan desa Sindang Jati Kecamatan Sindang Kelingi Kabupaten Rejang Lebong, seperti yang terjadi pada keluarga bapak Bahrun warga masayarakat Sindang Jaya yang beragama Islam memiliki orang tua beragama kristen dan anaknya pak bahrun yang bernama Lia beragama Kristen dapat hidup rukun dan damai, demikian halnya yang terjadi pada keluarga Ibu Setio yang beragama katolik, memiliki beberapa orang anak yang bernama samuji dan bardi, beragama Islam namun dapat hidup rukun dan harmoni dalam satu keluarga.

Fenomena satu keluarga beda agama, namun dapat hidup rukun dan harmoni ini banyak terjadi di Desa Desa Sindang Jaya Kecamatan Sindang Kelingi Kabupaten Rejang Lebong, berdasarkan hal-tersebut, peneliti melakukan penelitian yang berjudul "Keharmonisan Keluarga Beda Agama" (Studi Fenomena Keharmonisan Keluarga Beda Agama di Kecamatan Sindang Kelingi Kabupaten Rejang Lebong.

\footnotetext{
${ }^{2}$ Haninda Rafi W \& Dr. Sri Budi Lestari, Pola Komunikasi Keluarga Beda Agama dalam Membangun Keharmonisan, Jurnal Ilmu Komunikasi, 2017, h.2

${ }^{3}$ M. Karsayuda,. Perkawinan Beda Agama, Menakar Nilai-nilai keadilan KHI. Yogyakarta: Total Media, 2006, h. 60
} 
Fokus penelitian ini adalah mencari dan menggali informasi mendalam untuk mendapatkan jawaban tentang bagaimana pola perbedaan agama yang terjadi dalam satu keluarga di desa Sindang Jaya Kecamatan Sindang Kelingi Kabupaten Rejang Lebong serta bagaimana keharmonisan keluarga beda agama bisa terwujud di desa Sindang Jaya Kecamatan Sindang Kelingi Kabupaten Rejang Lebong?. Oleh karena itu, dengan adanya tulisan ini diharapkan dapat menjadi refrensi bagi keluarga yang lain untuk dapat mewujudkan keharmonisan dalam keluarga

Jenis penelitian yang peneliti lakukan guna mengungkapkan fakta tentang "Keharmonisan Keluarga Beda Agama Kecamatan Sindang Kelingi Kabupaten Rejang Lebong "(penelitian lapangan). (Akbar, 2003, p. 5) ${ }^{4}$ Di samping itu, penelitian ini juga menggunakan satu pendekatan yaitu pendekatan kualitatif dan metode deskriptir ${ }^{5}$

Menurut Bogdan dan Taylor (1975:5) penelitian kualitatif yaitu prosedur penelitian yang menghasilkan data deskriptif, dimana data yang dikumpulkan berupa kata-kata tertulis atau lisan dari orang-orang dan perilaku yang dapat diamati.

Adapun dalam mencari, data dan informasi serta mengumpulkannya, peneliti menggunakantiga teknik pencarian data, yaitu:

a) Observasi; pengmatan dilakukan secara intensif terhadap kehidupan dan aktifitas keluarga di sindang jaya, khususnya keluarga yang terdiri lebih satu agama. Hal ini dilakukan untuk mengetahui keharmonisan yang teerlihat dari kehidupan sehari-hari mereka serta komunikasi yang diterapkan dalam keluarga sehingga kerukunan bisa terwujud.

b) Wawancara (Interview)

\footnotetext{
${ }^{4}$ Case study research and field study research (Penelitian kasus dan penelitian lapangan) adalah penelitian yang bermaksud mempelajari secara intensif tentang latar belakang keadaan sekarang dan interaksi suatu sosial, individu, kelompok, lembaga dan masyarakat.

${ }^{5}$ M. Nazir, Metode Penelitian. Bogor: Ghalia Indonesia, 2005, h.89 "studi menemukan fakta dengan interpretasi yang tepat dimana termasuk di dalamnya termasuk studi untuk melukiskan secara akurat sifat-sifat dari beberapa fenomena kelompok dan individu serta studi untuk menentukan frekuensi terjadinya suatu keadaan untuk meminimalisasikan bias dan memaksimumkan reabilitas. Metode deskriptif ini digunakan untuk menjawab permasalahan mengenai seluruh variabel penelitian secara independen"
} 
Peneliti melakukan wawancara mengunakan teknik wawancara tak tersetuktur. Teknik ini peneliti pilih karena lebih bersifat luwes atau lentur dan dirancang agar sesuai dengan subjek dan suasana pada wawancara berlangsung ${ }^{6}$.

c) Dokumentasi

Adapun dalam analisis data, peneliti mendiskripsikan dan menguraikan tentang usaha yang dilakukan oleh keluarga beda agama di Sindang Jaya dalam mewujudkan keharmonisan. Setelah data terkumpul, maka data tersebut dianalisis untuk mendapatkan konklusi.Hal iti dilakukan dengan menggunakan beberapa metode, yaitu:

- reduksi data; data yang berkaitan dengan adanya keharmosian keluarga beda agama ini dikumpulkan kemudian dipetakan untuk dipilah dan dipilih mana data yang dibutuhkan dan mana data yang tidak dibutuhkan. Data yang dibutuhkan akan dilanjutkan untuk dianalisis dan data yang tidak dibutuhkan akan dibuang atau dikesampingkan.

- penyajian data; penyajian data ini sebagai salah satu bagian dari teknik menganalisis data yang bertujuan untuk memudahkan peneliti dalam memahami apa yang terjadi sebagai dasar untuk membuat rencana berikutnya.

- Conclusion Drawing; Langkah terakhir dalam analisi data sebuah penelitian adalah penarikan kesimpulan. Kesimspulan yang dikemukan di awal masih bersifat sementara. Kesimpulan itu akan berubah bila tidak ditemukan bukti yang kuat untuk mendukungnya atau ditemukan bukti yang justru malah berbeda dengan apa yang sudah disimpulkan.

Peneliti juga melakukan pengecekan data sehingga data penelitian menjadi lebih valid, pengecekan itu dilakukan dengan perpanjangan kehadiran peneliti, ketekunan pengamatan pada kehidupan keluarga beda agama dan Triangulasi (keabsahan data yang memanfaatkan sesuatu yang lain diluar data untuk keperluan pengecekan atau sebagai perbandingan

${ }^{6}$ Sugiyono. Metode Penelitian Pendidikan (Pendekatan Kuantitatif, Kualitatif Dan $R \& D)$. (Bandung: Alfabeta, 2015), 180. 
terhadap data ${ }^{7}$ seperti keterangan dari para tokoh masyarakat agama dan perangkat desa.

\section{Pembahasan}

\section{Keluarga \& Fungsinya}

Setiap orang pasti mendambakan memiliki keluarga, mereka tentu mendambakan keluarga yang hidup dengan kerukunan dan kedamaian. Berkaitan dengan definisi keluarga, Ki Hajar Dewantara memberikan definisi bahwasanya keluarga merupakan kumpulan dari beberapa orang yang menjadi satu gabungan secara esensial serta merasa nyaman hidup bersama-sama dikarenakan memiliki ikatan satu keturunan dari sebuah hasil perkawinan.

Adapun Salvicion dan Ara Celis, berpendapat bahwa keluarga adalah dua individu atau lebih yang memiliki hubungan darah serta hubungan perkawinan dan hidup dalam satu atap bingkai rumah tangga. Mereka saling berinteraksi dengan yang lain dan mereka saling menciptakan dan mempertahankan kebudayaan tertentu. ${ }^{8}$

Sedangkan dalam bahasa arab, keluarga disebut al-usratu berasal dari kata al-usru yang memiliki makna secara bahasa "ikatan". Meskipin demikian, Islam tidak menggunakan kata keluarga dengan kata al-usru melainkan al-ahl. Hal ini lebih dikarenakan keluarga bukan hanya sebuah ikatan, akan tetapi lebih dari itu keluarga merupakan sumber ketenangan diri, dan ketentraman. ${ }^{9}$

Ada lagi yang mendefinisikan keluarga dengan ikatan persekutuan hidup atas dasar pernikahan atau perkawinan antara dua orang dewasa yang berlainan jenis atau seorang laki-laki maupun perempuan yang sudah sendiri

\footnotetext{
${ }^{7}$ Sugiyono,Metode Penelitian Pendidikan (Pendekatan Kuantitatif, Kualitatif Dan $R \& D)$. Bandung: Alfabeta, 2015, h. 373-374.

${ }^{8}$ H. Hartono \& Arnicun Aziz, Ilmu Sosial Dasar. Jakarta: Bumi Aksara.,2008, h. 60

${ }^{9}$ Abdul Ghani Abud, Keluargaku Surgaku (Makna Perkawinan, Cinta, dan Kasih Sayang) Terjemahan Al-Usrah Al-Muslimah wa Al-Usrah Al-Mu"ashirah. Jakarta : Penerbit Hikmah, 2004, h. 24-28
} 
(janda/ dua) dengan anak kandungnya maupun anak adopsi dan hidup bersama dalam bingkai rumah tangga. ${ }^{10}$

Dari beberapa definisi diatas bisa dipahami bahwa Keluarga merupakan bagian terpenting dalam kehidupan, setiap orang akan bisa bercerita segala hal yang dihadapinya baik cerita itu menyenangkan atau menyedihkan kepada keluarganya. Dengan keluarga, orang berhadap akan mendapatkan ketentraman dan kenyamanan dalam kehidupan.

Keluarga merupakan bagian dari konsekuensi seseorang setelah diikat dengan perkawinan dan pernikahan. Keluarga memiliki fungsi yang penting dalam kehidupan, kehidupan akan menjadi tenang atau dalam bahasa agama disebut dengan sakinah, mawadah wa rahmah melalui keluarga. Menurut Soelaeman keluarga paling tidak memiliki delapan fungsi dalam kehidupan yaitu: fungsi edukasi, sosialisasi, proteksi, afeksi, religius, ekonomi, rekreasi, biologis. ${ }^{11}$

Hal yang hampir serupa juga disampaikan Djudju Sujana bahwa fungsi keluarga itu terbagi menjadi tujuh macam, yaitu: ${ }^{12}$

Fungsi edukatif, yang berarti bahwa keluarga merupakan tempat pendidikan yang awal dan pertama, orang tua memiliki peran terpenting untuk membawa anak-anaknya menjadi dewasa baik secara jasmani maupun rohani dalam tiga aspek (kognitif, afektif dan psikomotorik)

Fungsi biologis, yaitu fungsi keluarga dengan tujuan memiliki keturunan dan mampu memelihara martabat dan kehormatan manusia sebagai makhluk yang dikaruniai akal sehingga memiliki etika dan akhlak yang baik.

Fungsi protektif; yaitu menjadi tempat yang aman dari gangguan yang datang dari dalam maupun luar dan menghindarkan dari pengaruh negative yang masuk di dalamnya.

Fungsi religious; keluarga menjadi tempat untuk menanamkan nilainilai moral dan nilai-nilai agama dengan memberikan pemahaman,

\footnotetext{
${ }^{10}$ Ulfatmi, Keluarga Sakinah Dalam Perspektif Islam (Studi Terhadap Pasangan Yang Berhasil Mempertahankan Keutuhan Perkawinan di Kota Padang). Jakarta: Kementrian Agama Republik Indonesia, 2011, h. 19

${ }^{11}$ Moh. Padli \& Triyo Supriyanto, Sosiologi Pendidikan. Malang: UIN-Maliki Press, 2010, h. 118-120

${ }^{12}$ Mufidah ch, Pardigma Gender. Malang: Bayumedia Publishing, 2004
} 
penyadaran, dan aplikasi ibadah dan muamalah sehari-hari sehingga tercipta keluarga yang biasa disebut dengan religious

Fungsi ekonomi; keluarga merupakan kesatuan ekonomis dimana dalam keluarga ada aktivitas seperti menncari nafkah, pembinaan usaha, perencanaan anggaran serta tata cara pengelolaan harta dan kekayaan yang dimiliki sehingga dapat dipertanggungjawabkan secara social dan moral

Fungsi sosialisasi; keluarga memiliki tanggung jawab dalam mempersiapkan generasi yang baik dalam hidup bermasyarakat serta mampu memegang norma-norma kehidupan secara universal.

Fungsi rekreatif; fungsi keluarga dalam menciptakan suasana saling menghormati, hubungan yang harmonis, kasih sayang dan damai

Dari fungsi di atas, kita bisa mengetahui bahwa keluarga berusaha untuk selalu hadir mempersiapkan anak keturunannya dengan mengenalkan sikap-sikap dan nilai-nilau yang bisa diterima oleh masyarakat serta sesuai dengan norma-norma yang berlaku. Ketika seseorang bisa mewujudkan fungsi-fungsi keluarga tersebut, maka ketentraman dan ketenangan hidup rumah tangga akan senantiasa bisa terwujud.

Di samping itu, Negara melalui peraturan pemerintah juga menjelaskan tentang fungsi keluarga. Hal itu, terihat dalam peraturan pemerintah RI Nomor 21 Tahun 1994, tentang keluarga yang menyebutkan bahwa fungsi keluarga di tengah masyarakat ada 8, yaitu: fungsi sosial budaya, fungsi keagamaan, fungsi cinta kasih, fungsi melindungi, fungsi reproduksi, fungsi sosialisasi dan pendidikan, fungsi ekonomi, dan fungsi pembina lingkungan

\section{Keharmonisan}

Dalam definisinya, KBBI menyebutkan bahwa harmonis memiliki arti serasi, selaras. Titik berat dari keharmonisan adalah keadaan selaras atau serasi. Keselarasan dan keserasian dalam kehidupan bisa dicapai dengan adanya keharmonisan. Oleh karena itu, Keluarga harus betul-betul menjaga hal itu sehingga bisa memunculkan kebahagian dalam rumah tangga. ${ }^{13}$

${ }^{13}$ Tim Penyusun Kamus,Kamus Besar Bahasa Indonesia. Jakarta: Departemen Pendidikan dan Kebudayaan, 1989 
Pendapat lain mengatakan bahwa keluarga harmonis adalah keluarga yang mampu menciptakan ketenangan, ketentraman, kasih sayang, keturunan dan kelangsungan generasi masyarakat, saling melengkapi, saling mengasihi, rela berkorban dan saling bekerja sama untuk saling menyempurnakan. ${ }^{14}$

Harmonis, juga semakna dengan kata "rukun" sebagai kata sifat yang berarti cocok, selaras, sehati, tidak berselisih.Dalam bahasa inggris, disepandankan dengan harmonius.Dengan demikian kerukunan berarti kondisi sosial yang ditandai oleh adanya keselarasan, kecocokan, atau ketidak berselisihan (harmony). Dalam literatur sosial, kerukunan diartikan dengan istilah integrasi (lawan disintegrasi) yang berarti the creation and maintenance of diversified patterns of interactions among autonomous units(kerukunan merupakan kondisi dan proses yang tercipta dan terpeliharanya pola-pola interaksi yang beragamdi antara unit-unit yang otonom). Kerukunan mencerminkan hubungan timbal balik yang ditandai oleh sikap saling menerima, saling mempercayai, saling menghormati dan menghargai, serta sikap saling memaknai kebersamaan. ${ }^{15}$

Adapun fakor-faktor yang memepengaruhi keluarga harmonis yaitu: ${ }^{16}$

a. Kesejahteraan jiwa; tidak adanya pertikaian dalam rumah atau paling tidak frekuensi pertengkahan dalam rumah tangga sangat sedikit sekali. Keluarga tersebut tetap saling mengasihi, saling merasa membutuhkan dan tolong menolong. Kepuasan satu dengan yang lain menjadi indicator adanya jiwa yang bahagia.

b. Kesejahteraan fisik; banyaknya dan seringnya anggota keluarga sakit, banyaknya kebutuhan terhadap obat dan medis bisa menjadi penghambat terwujudnya keharonisan dan kesejahteraan keluarga.

c. Keseimbangan antara pengeluaran dan pendapatan keluarga; kemampuan secara menejerial dalam mengelola dan menyeimbangkan antara pengeluaran dan pendapatan keluarga menjadi bagian dari wujud keharmonisan keluarga, apabila antara pemasukan dan pengeluaran tidak seimbang maka bisa dipastikan akan sulit untuk mewujudkan keluarga yang harmonis dan sejahtera

\footnotetext{
${ }^{14}$ Ali Qaimi, Menggapai Langit Masa Depan Anak. Bogor: Cahaya, 2002, h.14

${ }^{15}$ M. Ridwan Lubis, Meretas Wawasan dan Praksis Kerukunan Umat Beragama di Indonesia . Puslitbang, 2005, h. 7-8

${ }^{16}$ (Sarwono, 2002)
} 
54 | FOKUS : Jurnal Kajian Keislaman dan Kemasyarakatan Vol. 5, No. 1, 2020

\section{Keluarga Beda Agama}

Beberapa Keluarga beda Agama yang ada di desa Sindang Jaya dan dapat hidup harmonis yaitu:

Keluarga bapak Suranto, ${ }^{17}$

Bapak Suranto memeluk agama Budha beserta istrinya bernama Wasti, sedangkan anaknya memeluk agama Islam. Menurutnya, anaknya masuk Islam semenjak menikah. Ia memberikan keleluasaan kepada anakanaknya dalam meilih keyakinan. Baginya tidak ada paksaan dalam memilih agama terlebih anaknya juga sudah dewasa. Dalam kehidupannya, ia mengaku tidak pernah menjadikan perbedaan agama tersebut sebagai alasan untuk bertikai. Kegiatan dalam keluarga berjalan seperti biasa dan makanpun tetap bersama.

Pada hari raya Islam, ia menceritakan bahwa anaknya juga tetap melakukan sungkem dan meminta maaf kepada orang tuanya sebagaimana yang dilakukan keluarga muslim lainnya. Orang tua juga senantiasa mengingatkan akan kewajiban sebagai pemeluk agama, jangan sampai ketika sudah memluk islam tidak mau melakukan apa yang sudah diwajibkannya.

Dari wawancara tersebut, toleransi yang teercipta sangat luar biasa.Saling mengerti dan saling menghormati dalam keluarga menjadi satu alasan keluarga tersebut tetap harmonis.Mereka justru saling mengingatkan untuk senantiasa rukun dan harmonis dalam keluarga. Adapun konstruksi perbedaan agama dalam keluarga ini yaitu (orang tua = budha dan anak $=$ muslim)

\section{Keluarga Bapak Gusdiyanto}

Bapak ini memeluk agama katholik beserta istri dan anaknya bernama Rasti yang memeluk agama Islam. Mereka hidup bersama dalam satu rumah. Beliau mengatakan "saya selalu berpesan kepada anak-anak untuk senantiasa hidup rukun, berbeda tetapi tetap bersaudara, seluruh agama mengajarkan kebersamaan dan kerukunan untuk tidak saling menggannggu dan menyakiti."

Rasti memeluk Islam semenjak ia dinikah. Hidup bersama dengan berbeda agama tidak menjadikan alasan tidak harmonis.Kehidupan dan

${ }^{17}$ Wawancara dengan keluarga beda agama desa Sindang Jaya Kab. Rejang Lebong 
komunikasi tetap berjalan sebagaimana hubungan anak dan orang tua.ketika sang ayah merayakan Natal, sang anak selalu siap membuatkan kue sebagai ucapan selamat, sedangkan ketika hari raya idul fitri, sang anak meminta maaf kepada orang tuanya. Dalam hal makan, mereka tetap makan seperti biasa; makan bersama tanpa memisah-misahkan makanan di rumah.Sang ayah juga sering mengingatkan untuk melaksanakan ibadah shalat jumat pada hari jumat. Meskipun demikian, Wasti mengaku kalau ia masuk islam belum dapat melaksanakan kewajibannya secara utuh. Shalat lima waktu belum bisa ia lakukan secara sempurna.

Toleransi yang berlangsung dalam keluarga ini menjadikan keharmonisan bisa terwujud.Tidak ada lagi alasan untuk tidak bisa rukun dalam keluarga. Bagi mereka kerukunan di atas segala-galanya, hidup untuk saling mengerti dan mengingatkan akan pentingnya kebersamaan, cinta dan saling menyayangi menjadikan mereka tetap utuh dalam satu keluarga. Perbedaan agama dalam keluarga ini yaitu (orang tua =katholik dan anak =muslim)

\section{Keluarga Sugatijem,}

Seorang nenek yang beragama katholik. Dua anaknya bernama Herman \& Seri beragama Islam. Keluarga ini tetap hidup rukun dan harmonis. Dari segi kehidupan, sang nenek mengatakan bahwa makanan yang dimasak dan disiapkan itulah yang dimakan bersama tanpa membedabedakan. Sang anak setiap jumat juga berangkat ke masjid untuk melaksanakan shalat jumat. Ibunya senantiasa mengingatkan untuk taat dan patuh dengan aturan agama yang sudah diyakini dan dianutnya.

Setiap ada perayaaan, -sebagaimana keluarga yang lain di atasmereka saling membantu dan menyumbangkan kue dan makanan untuk disajikan dan diberikan kepada anggota keluarga yang merayakan. Saat ramadhan tiba, nenek sugatijem mempersiapkan makanan baik untuk berbuka maupun sahur.Ia juga rajin membangunkan anak-anaknya untuk makan sahur. Toleransi dan saling pengertian semacam ini menjadikan keluarga mereka tetap harmonis meskipun dengan keberagaman yang ada. Perpindahan agama yang dilakukan itu berawal ketika sang anak ingin menikah.

\section{Ibu Erli,}


Ibu Erli adalah salah satu warga di desa sindang jaya yang beragama katolik. Ibu Erli ini dahulu beragama Islam, ia berasal dari desa Pelalo dan menikah dengan Bapak Sulianto beragama katolik. Ia memiliki anak perempuan yang beragama Islam. Mereka tinggal satu rumah.

Menurut bu Erli, "dalam kehidupannya tidak pernah terjadi permasalahan yang berkaitan dengan perbedaan agama". Mereka mengaku hidup dengan rukun dan harmonis, komunikasi terjalin dengan baik dan aktifitas berjalan seperti biasa tanpa terbebani dengan perbedaan tersebut.

Sama halnya dengan keluarga yang lain, ibu erli memandang bahwa seluruh agama pada dasarnya menginginkan kebaikan dan ketentraman, tidak ada satu agama apapun yang mengajarkan permusuhan, kerusuhan dan perusakan. Oleh karena itu, baginya ketika anak sudah dewasa dan menentukan pilihan keyakinan dalam memeluk agama, ia memberikan kelonggaran dan kebesan.

Anaknya juga menyampaikan, bahwa sang ibu juga rajin memberikan pesan "ketika sudah menentukan pilihan keyakinan, maka laksanakan keyakinan tersebut sebaik mungkin dengan menjalankan atura-aturan dan perintah yang ada di dalalmnya." Setiap ada perayaan hari besar baik natal maupun hari

\section{Keluarga Bapak T. Samuji}

Beliu adalah anak pertama dari enam bersaudara, lima orang saudaranya masuk Islam dan satu masih beragama katolik. Orang Tua beliau bernama Bapak taman dan Ibu Yatijah (beragama Katolik) T. Samuji masuk Islam pada tanggal 28 Februari 1982, dan menikah dengan Ibu Mutiara Dewi (suku lembak beragama Islam) pada tanggal 25 Oktober 1985, T. Samuji adalah alumni Sekolah Tinggi Seminari Jurusan Teologi Filsafat di Bogor dan Jogja tetapi setelah melalui proses berfikir yang mendalam akhirnya masuk Islam. Saat masuk Islam, justru orang-orang Islam tidak percaya dengan ke-Islamnnya. Namun dengan berjalannya waktu ia diterima dengan baik oleh warga Sindang Jaya. Alasan sebagian masyarakat pindah agama menurut beliau karena faktor perkawinan, karena saat menikah baik dalam agama Islam maupun agama Kristen harus seagama. 
Setelah menikah, Walapun Bapak T. Samuji telah masuk Islam bersama istrinya, namun tetap menjalin hubungan baik dengan saudara dan orang tua beliau yang beragama katolik, bahkan setiap lebaran Paskah Bapak T. Samuji bersama Istri selalu berkunjung dan membuatkan makanan dan menu khusus untuk orang tua beliau. Beliau melanjutkan, pernah suatu ketika umat Budha kehilangan lonceng Viharanya yang dicuri orang, masyarakat yang beragama Islam ikut membantu untuk mencari dan mengejar pencurinya, al hasil lonceng tersebut ditemukan oleh mereka dan diserahkan kepada umat budha. Inilah di antara contoh gotong royong dan kebersamaan yang dipraktekan oleh masyarakat di Sindang jaya sejak puluhan tahun yang lalu bahkan sampai saat ini.

\section{Keluarga Ibu Jamilah}

Ibu Jamilah (Islam) memiliki anak bernama Sukandi, masuk katholik setelah menikah dengan Elis (Katholik). Akan tetapi uniknya, bapaknya Elis yang bernama Edi, masuk Islam disebabkan menikah dengan ibu Marthin yang beragama Islam. Mereka berbeda agama dan pindah agama disebabkan faktor perkawinan. Keluarga ini hidup dalam satu rumah dan harmonis tanpa mempersoalkan perbedaan dan perpindahan agama. Dari penjelasan tersebut, diketahui begitu hebatnya saling mengerti dan menghormati sehingga bisa terwujud keharmonisan dalam keluarga.

\section{Faktor Keharmonisan Keluarga ${ }^{18}$}

\section{Hubungan kekerabatan.}

Masyarakat Desa Sindang Jaya adalah masyarakat transmigrasi yang dilaksanakan pada era presiden Soekarno pada Tahun 1956. Yang berasal dari beberapa daerah seperti Banyumas, Yogyakarta (Kulon Progo), Wono Sari, dan Semarang. Agama yang dianut oleh mayoritas transmigran dari Yogyakarta adalah Islam, transmigran dari Solo beragama katolik, dan agama Budha yang dibawa oleh transmigran dari semarang. Setelah mereka pindah di Sindang Jaya hubungan kekerabatan mereka semakin erat karena perkawinan se-agama dan perkawinan lintas agama, sehingga mereka memiliki hubungan kekerabatan antara yang satu dengan yang lain. Selain karena perkawinan hubungan kekerabatan juga terjadi karena interaksi

\footnotetext{
${ }^{18}$ Wawancara dengan tokoh masyarakat setempat dan Bapak Juwarto Mantan kepala desa sekaligus sesepuh di desa Sindang Jaya, menjadi kepala desa selama 16 tahun dan sebagai orang tua dari kepala desa sekarang.
} 
saling mengangkat keluarga seperti keluarga Romo Sulyono Veteran beragama Budha (bikui) yang mengakat bapak Juwarto mantan kepala desa (beragama Islam) sebagai anak, sehingga masyarakat Desa Sindang Jaya hidup rukun dan saling menghormati satu dengan yang lain.

\section{Merasa Senasib Sepenanggungan.}

Warga masyarakat Desa Sindang Jaya adalah masyarakat yang berasal dari keluarga veteran yang ikut program transmigrasi yang berasal dari Semarang, Solo dan Jogjakarta, sehingga kesamaan Suku dan daerah asal-usul membuat mereka memiliki rasa senasib sepenangungan untuk hidup bersama ditempat yang baru dan membangun masa depan bersamasama.

\section{Kesamaan Pekerjaan/ Profesi Orang Tua}

Terwujudnya keharmonisan dan kerukunan baik skala luas (masyarakat) maupun skala kecil (keluarga), ini terbentuk sudah sejak zaman orang tua dan kakek-nenek mereka. Orang tua mereka yang pindah demi memperbaiki ekonomi dengan ikut program transmigrasi memiliki kesamaan dalam profesinya. Mereka sama-sama Veteran angkatan darat yang aktif ikut serta dalam melawan kolonialisme penjajah demi menjaga keutuhan negara, keseleamatan diri dan keluarga. Profesi dan perjuangan yang sama inilah menjadi cikal bakal tumbuhnya kerukunan di antara mereka yang kuat dan tak tergoyahkan. Tidak selesai di situ, sifat rukun, ramah, dan saling menghargai ini berhasil mereka wariskan kepada anak cucunya sampai saat ini

\section{Nasehat dari Para Sesepuh Untuk Hidup Rukun.}

Salah satu faktor penyebab kerukunan di Desa Sindang Jaya adalah Nasehat yang disampaikan para pendiri dan sesepuh Desa untuk hidup rukun dan saling menghargai walaupun berbeda agama dan keyakinan. Seruan para sesepuh untuk menjaga kerukunan disampaikan kepada masyarakat baik dalam acara formal maupun informal, seperti pada upacara 17 Agustus, Doa Sedekah bersih Desa yang dilaksanakan tiap tanggal 1 Suro, saat warga berkumpul di acara hajatan Warga, gotong royong dan lain-lain.

\section{Adanya peraturan Desa (Perdes) untuk hidup harmoni dan saling menghormati}


Peraturan dibentuk di berbagai bidang itu memiliki tujuan yang sama, yakni ketertiban, kenyamanan, keamanan, dan keselamatan. Orang yang tidak bisa diatur biasanya terkesan radikal dan keras. Mereka mau melakukan sesuatu sesuai kemauan mereka tanpa memperhatikan orang lain dan akibatnya. Adanya perbedaan agama yang hidup bersama diakui atau tidak bisa menjadi pemicu koflik. Sebagaimana kita lihat di Rohingnya, banyak muslim menjadi korban atas tindakan dari umat budha yang tidak mengerti akan tujuan agama. Dengan melihat ini, kepala desa Sindang Jaya selaku pimpinan tertinggi membuat Perdes tantang hidup rukun dan saling menghormati antar agama dan ormas. Beliau menyadari keberagaman keyakinan yang ada di sana kalau tidak dibantu dengan peraturan desa akan sedikit rumit untuk mewujudkan keharmonisan tersebut

\section{Pandangan moderat tokoh agama}

Orang yang ditokohkan haruslah mampu mendinginkan suasana dengan ucapan, perintah maupun himbauan yang didengarkan oleh masyarakat ketika terjadi perselisihan. Hal tersebut terbukti di desa sindang jaya, tokoh masyarakat menjadi sentral dalam mengontrol masyarakat. Keberagaman agama yang ada di dalamnya tidak menimbulkan gesekan sedikitpun. Tokoh agama yang ada, baik islam, budha, dan katholik senantiasa menghimbau dan mengingatkan masyarakat akan pentingnya hidup rukun dan harmonis, begitu juga dalam berkeluarga. Bahkan mereka tidak memaksa untuk menentukan pilihan agama. Bagi mereka keyakinan agama itu murni dari hati nurani sehingga tidak bisa dipaksakan. Tokoh agama moderat semacam inilah yang menjadi salah satu faktor bisa terwujudnya kerukunan berbeda agama bahkan dalam keluarga. Jangan sampai tokoh agama memiliki sifat radikal dan keras sebagaimana Ashin Wirathu pimpinan budha di Rohingnya atau kasus Islam dan Kristen di Papua yang terjadi waktu lalu.

\section{Kesimpulan}

Perbedaan agama dalam keluarga yang terjadi di desa Sindang Jaya terjadi antara keluarga yang terdiri dari orang tua muslim dan anaknya katolik atau sebaliknya danada pula yang buda dan muslim dalam satu keluarga. Perbedaaan agama dalam keluarga yang terjadi ini tidak menjadi hambatan bagi keluarga di Sindang Jaya dalam mewujudkan keharmonisan dan kerukunan, mereka tetap hidup bahagia bersama. Bagi mereka 
60 | FOKUS : Jurnal Kajian Keislaman dan Kemasyarakatan Vol. 5, No. 1, 2020

kerukunan dan keharmonisan adalah hal utama dan menjadi prinsip hidup yang sudah diajarkan oleh orang tua mereka.

\section{Daftar Pustaka}

Abud, A. G. (2004). Keluargaku Surgaku (Makna Perkawinan, Cinta, dan Kasih Sayang) Terjemahan Al-Usrah Al-Muslimah wa Al-Usrah Al$M u$ "ashirah. Jakarta : Penerbit Hikmah.

Aziz, H. H. (2008). Ilmu Sosial Dasar. Jakarta: Bumi Aksara.

ch, M. (2004). Pardigma Gender. Malang: Bayumedia Publishing.

Erni Suhesti, S. (n.d.). Harmoni Keluarga Beda Agama di Melati Sleman Yogya. As Syi'ah.

Kamus, T. P. (1989). Kamus Besar Bahasa Indonesia. Jakarta: Departemen Pendidikan dan Kebudayaan.

Karsayuda, M. (2006). Perkawinan Beda Agama, Menakar Nilai-nilai keadilan KHI. Yogyakarta: Total Media.

Lestari, H. R. (2017). Pola Komunikasi Beda Agama dalam Membangun Keharmonisan. Ilmu Komunikasi.

Lubis, M. R. (2005). Meretas Wawasan dan Praksis Kerukunan Umat Beragama di Indonesia. Puslitbang.

Nazir, M. (2005). Metode Penelitian. Bogor: Ghalia Indonesia.

Qaimi, A. (2002). Menggapai Langit Masa Depan Anak. Bogor: Cahaya.

Sarwono, S. W. (2002). Menuju Keluarga Bahagia. Jakarta: Bathara Karya Aksara.

Sugiyono. (2015). Metode Penelitian Pendidikan (Pendekatan Kuantitatif, Kualitatif Dan $R \& D)$. Bandung: Alfabeta.

Supriyanto, M. P. (2010). Sosiologi Pendidikan. Malang: UIN-Maliki Press.

Ulfatmi. (2011). Keluarga Sakinah Dalam Perspektif Islam (Studi Terhadap Pasangan Yang Berhasil Mempertahankan Keutuhan Perkawinan di Kota Padang). Jakarta: Kementrian Agama Republik Indonesia. 